\title{
The Frontier in Process: Iowa's Trail Women as a Paradigm
}

\author{
Glenda Riley
}

D URING THE NINETEENTH CENTURY the western portion of America exploded into an unbelievable multitude and variety of frontier regions. Some sprang up overnight while others disappeared overnight; most, however, were created gradually and peopled incrementally. In time, they usually prospered and became the stuff from which dreams were being shaped not only in the rest of the United States but throughout much of the world.

There was no neat line or pattern to these developments. Frontiers did not march across the western portion of the continent from the Ohio Valley to the Pacific Ocean. They appeared wherever there was land, gold, lumber, or some other asset that was attractive enough to draw people from their homes like a magnet. Neither was there any line where any particular frontier began. Signing a deed or pounding in a claim stake might mark a settler's arrival, but it did not mark the beginning of a settler's frontier. On the contrary, the pioneer's frontier experience actually began sometime during the transitional phase between the old and the new, the settled and the frontier, the East and the West.

That transitional link was the trail-the time spent and the space crossed by settlers in order to reach their chosen frontier. 
As they were traversing this link the pioneers were not living in suspended animation. They did not board their wagons in Vermont and descend a few hours later on the edge of a verdant prairie or a raw gold field as a modern jet traveler might. Rather, they invested many weeks or months as well as untold amounts of physical and psychic energy to get to the frontier region which promised them so much. The trail was not a pleasure trip, a joyride, or a vacation. It was difficult work for people to transport themselves from the known to the unknown. It was even more difficult for them to create the necessary metamorphosis in themselves which changed them from the settled into the settlers. In short, the trail was not just a prelude to a frontier which suddenly began when a river was crossed or an artificially drawn boundary line was reached. The trail was a kind of frontier in itself; a temporary frontier of a community in movement. The trail was a frontier in transit, a frontier in motion, a frontier in the process of becoming. ${ }^{1}$ As a result, the trail experience was serious business because it was the first chapter of frontier life. What the migrants did, said, thought, and learned on this moving frontier helped shape the outcome of their own personal dramas.

Migrants had to apply their energies to four basic areas of endeavor while on the trail: 1) performing the chores connected with daily living, now with the duress of the trail environment added; 2) physically moving themselves to their promised land; 3) learning, practicing, and honing the skills that would spell survival in their new homes; and 4) reshaping their psychological mind-set from looking back to the East to looking forward to the West. Some were successful in these areas, others were less so. Some were enthusiastic about the venture, others were not. But for good or ill, once on the trail they were already part of the surging and demanding American frontier.

What did the rigors of this frontier in transit mean to women in particular? As casual observers and serious scholars tried to fathom the ways the trail affected the women who tackled it, a predominant generalization emerged. This image pictured a

${ }^{1}$ Allan G. Bogue, "Social Theory and the Pioneer," Agricultural History 34 (January 1960): 24. 
forlorn, beleaguered trail woman forced to leave her comfortable home by a dominant husband blind with wanderlust. Due to her supposedly inherent weakness and domestic nature she begged her husband at every opportunity to turn back east, she choked in the dust, she became weathered in the sun, and she continuously bemoaned her fate and that of her poor children in a primitive land. ${ }^{2}$ Somehow this portrait, although widely accepted and certainly supported by actual cases of women who did suffer, does not ring quite true. Its generality, the inclusiveness of its terms, are themselves cause for suspicion. But how can it be tested when there were so many trails during so many eras heading for so many destinations? Clearly, it can only be tested, in a sense, trail by trail. If it is found wanting on even one trail then the mandate is evident: other trails during other times to other places must be examined more thoroughly and objectively as well.

In many ways, the Iowa-bound trail was typical of other frontier trails, especially those to family-farm frontiers. As such, the Iowa trail is a useful case study. It was an episode which began with early white squatters in Iowa's Half-Breed Tract in 1828 and had more or less vanished by 1870 , the United States Census Bureau's official closing date for the Iowa frontier. Its travelers originated primarily in the farm areas of the Ohio Valley, then in the southern states, the middle states, the New England states, and other countries. Many came seeking a better climate, improved health, richer land, or a more promising future for their children. Others set out to escape inordinate taxation, the system of black slavery, or personal

${ }^{2}$ See for example John Faragher and Christine Stansell, "Women and Their Families on the Overland Trail to California and Oregon, 1842-1867," Feminist Studies 2 (1975): 150-166; John Faragher, Women and Men on the Overland Trail (New Haven: Yale University Press, 1979); Dorys C. Grover, "The Pioneer Women in Fact and Fiction," Heritage of Kansas: A Journal of the Great Plains 10 (Spring 1977): 35-44; Emerson Hough, The Passing of the Frontier (New Haven: Yale University Press, 1921), especially 93-94; Georgia Willis Read, "Women and Children on the Oregon-California Trail in the Gold Rush Years," Missouri Historical Review 34 (October 1944): 1-23; Lillian Schlissel, "Women's Diaries on the Western Frontier," American Studies 18 (Spring 1977): 87-100; Page Smith, Daughters of the Promised Land (Boston: Little, Brown and Company, 1970), especially 223; Christine Stansell, 
financial problems. Most migrated in extended family units which often included or were supplemented by both single men and women. And although there were no census-takers on the trail, later territorial and state census data indicated that most migrated to take up land and become farmers. ${ }^{3}$

From these factors several additional characteristics of the Iowa trail can be intuited. The abundance of families indicates a high proportion of women and children on the trail. The capital needed to make the trek, purchase seed and tools, and invest in land suggests that, despite popular belief, the very poor were not common among the migrants. And the fact that most migrants were agrarian in background means that they already had some training in the skills they needed to make the westward move.

In other ways, the Iowa trail was less representative, particularly of overland routes to the Far West. Most Iowa-bound settlers were traveling over parts of the country which were comparatively well-settled, a situation which created a certain amount of ease for them in that they could occasionally buy supplies along the way and could sometimes stay at inns or campgrounds. References to fresh produce, friendly shopkeepers, and campgrounds established specifically for the covered wagon people abound in the diaries and letters of Iowa pioneers. This is not to argue that their time on the trail was easy, but there is little in their history or mythology to compare with the tragedy of those trapped for a winter at Donner Pass.

Because of the settled nature of the countryside through which they traveled, Iowa-bound migrants had relatively little to fear in the way of confrontations with Native Americans. Land

"Women on the Great Plains, 1865-1890," Women's Studies 4 (1976): 87-98. For a discussion of images and their development see Glenda Riley, "Images of the Frontierswomen: Iowa as a Case Study," Western Historical Quarterly 3 (April 1977): 189-202; "Women in the West," Journal of American Culture 3 (Summer 1980): 311-329; and Beverly J. Stoeltje, "'A Helpmate for Man Indeed:' The Image of the Frontier Woman," Journal of American Folklore 88 (January-March 1975): 25-41.

${ }^{3}$ Allan G. Bogue, From Prairie to Corn Belt: Farming on the Illinois and Iowa Prairies in the Nineteenth Century (Chicago: Quadrangle Books, 1968): 22-33; Martin Ridge, "Why They Went West," The American West 1 (Summer 1964): 40-57; Iowa Census of 1880, 57, 168-170. 
treaties, President Andrew Jackson's removal policy, and outright genocide had essentially cleared the portion of the United States lying northeast of the Mississippi River of native populations. Indians valiantly resisting white encroachments did not play a notable role in the recounting of the Iowa trail saga.

Moreover, besides moving through populous countryside, these settlers were moving westward in a time period marked by increasing industrialization and technology which supplied them with a variety of modes of transportation. Legend to the contrary, the covered wagon was not the only alternative in existence in mid-nineteenth-century America. Given the media image of pioneers, it is rather startling to learn that many of them actually opted for other means of conveyance to the Iowa frontier.

Riverboats, for example, were one widely-used type of transportation. When the Harris family came to Iowa from Pennsylvania they chose to go virtually the entire way by river. A daughter wrote that the boats carried them "first down the Allegheny to Pittsburgh; thence down the Ohio River on the steamboat, 'the Diadem,' to Cairo; thence on the 'New England' up the Mississippi to Keokuk." She commented that although they traveled in deck passage to economize, they remembered it as a speedy and enjoyable trip, often made pleasurable by the company and song of other passengers. ${ }^{4}$

Rail routes were another possibility. Leaving New Hampshire in 1855, the Motts chose a rail route all the way to the Iowa line. They began their journey going by railroad first to Boston then on to Niagara Falls where they crossed the suspension bridge into Canada. They continued on the railway until the end of the line of the Mississippi River across from Dubuque. On the last lap of the trip they took a steamboat to Lansing in northeastern Iowa and finally engaged stage passage to Decorah, their final destination. ${ }^{5}$ In 1858, the Newtons tried a slightly different combination. They began their trip with a stagecoach ride from their Connecticut home to Fair Haven where they boarded a

"Joanna Harris Haines, "Seventy Years in Iowa," ed. Frank Herriott, Annals of Iowa 27 (October 1945): 98.

${ }^{5}$ Abbie Mott Benedict, "My Early Days in Iowa," Annals of Iowa 17 (July 1930): 331. 


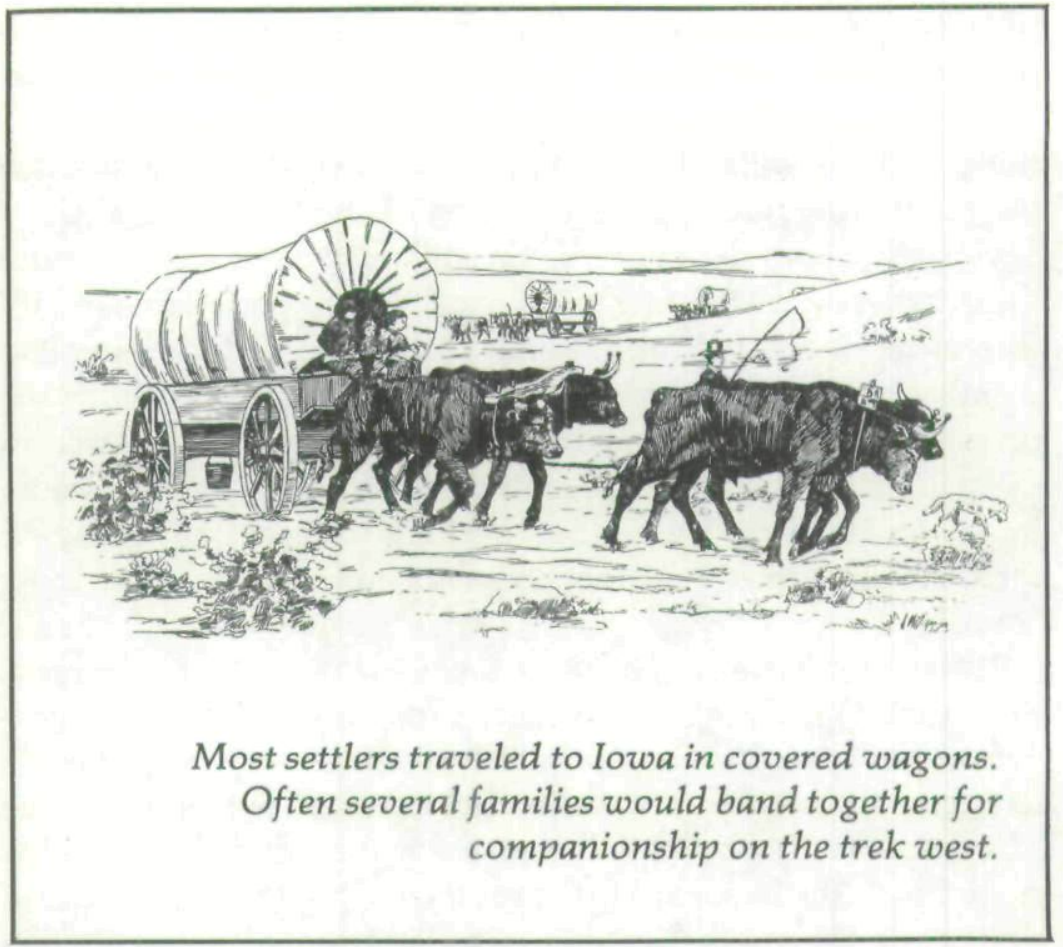

steamboat to New York. There they boarded "the cars" for Chicago and after visiting the city for a few days, they again boarded the cars for Davenport. They then rode to the end of the rail line in Louisa County, Iowa, where they hired a driver and team to transport them to their new home in Keokuk County. ${ }^{6}$

As the various steamboat and railroad companies increased their services, improved their facilities, and multiplied their routes, more settlers selected them as a quick and easy means of moving to Iowa. But despite these attractions, both the boats and "cars" had some serious disadvantages. Space limitations curtailed the settler's needs and desires to move household goods, farm implements, seed, stock, and even clothing. Because such goods were more in demand and thus more expensive in Iowa than back East, the unequipped settler could expect some difficulty in obtaining goods as well as some expense in

${ }^{6}$ Edith H. Hurlbutt, "Pioneer Experiences in Keokuk County, 1858-1874," Iowa Journal of History 52 (October 1954): 327-328. 
paying for them. In addition, boat and rail fares were expensive and were often prohibitive if more than two or three members of the family were making the trip.

In the face of these drawbacks, the overwhelming majority of Iowa's pioneers elected to use covered wagons. Although they had the deserved reputation of being slow and awkward, their unwieldy bulk accommodated family members, goods, equipment, and animals. The journey would take considerably longer than it would by boat or rail, but the migrants would enjoy the initial advantage of having their belongings, seed, and stock with them in a territory with little surplus. And, if necessary, the prairie schooner, as it was known, could even become a temporary home for the settlers when the trail finally came to a welcome end.

A trmough they did not express it overtly, most pioneers recognized the trail as the beginning of the frontier. Realizing the magnitude of their undertaking they focused their mental and physical efforts on each minute detail of the trip ahead. They already knew from emigrants' guides, word-of-mouth, and personal accounts that any small oversight or lack of attention to a petty detail could make the difference between success and failure, between survival and destruction. So family members worked on the necessary preparations as a team, but like any effective team they divided the labor according to the skills of the individuals involved. This of course meant a traditional division of labor. Because of their long experience with machinery and stock the men took responsibility for the wagon and its team. The women, on the other hand, worked long and hard to prepare the needed clothing, bedding, kitchenware, and foodstuffs for the trip.

In practice, however, the division was not this clear. Men and women helped each other whenever possible, overlapped duties, and shared tasks. In the case of the wagon the men usually made the final selection. They chose from two basic types: the large Conestoga wagon which was approximately fifteen feet long, five feet wide, and five feet deep or the smaller, 
lighter Emigrant wagon which measured about ten feet in length, four feet in width, and two feet in depth. ${ }^{7}$ Their choice was based on how much they wanted to carry and how fast they wanted to travel. In either style they looked for a sturdy, well-constructed box which would not shake apart on some desolate stretch of trail. Once the wagon was selected, the men were expected to equip it with running gear as well as to find and train suitable animals to haul it and its contents hundreds of miles through sun, dust, rain, mud, and snow.

At this point the women took over for the final segment of the wagon consisted of the cloth top, the production of which was assigned to the women of the family due to their familiarity with fabrics and their sewing skills. This was a long-term and difficult job since the top was frequently stitched by hand. In planning a wagon cover for one of their journeys, Kitturah Belknap explained that she would "make a muslin cover for the wagon as we will have a double cover so we can keep warm and dry; put the muslin on first and then the heavy linen one for strength. They both have to be sewed real good and strong and I have to spin the thread and sew all those long seams with my fingers." According to Belknap, time and expertise by the woman or women were the two essential ingredients needed to produce a roof which would successfully shelter the travelers from inclement weather during their long westward journey. ${ }^{8}$

While the production of the cover was progressing, women, aided by the men and children, were also giving much thought to the equipping of the wagon box. The degree of thoughtfulness and efficiency expended on this task could also spell disaster or success for the migrants. A family's entire future had to be assembled and packed in that limited space. This meant that every item they owned or purchased had to be critically examined in terms of its potential usefulness on the Iowa frontier. Equipment had to include all the clothing, food, cooking utensils, bedding, medicines, and tools that might be necessary to sustain family and animals along the trail as well as seed, farm

${ }^{7}$ B. J. Zenor, "By Covered Wagon to the Promised Land," The American West 11 (July 1974): 32-33.

${ }^{8}$ Kitturah Penton Belknap, "Reminiscences," Iowa State Historical Department, Division of the State Historical Society, Iowa City, Iowa. 
implements, and furniture to carry them through the beginning phases of establishing a homestead.

Although equipping the box was a chore involving both men and women, there was still something of a division of labor along customary lines. The men usually readied items such as firearms, tools, and furniture. They also utilized every possible space on the outside of the wagon box to hang buckets of grease to be used for the axles, barrels of water for the stock, and spare parts for the wagon. Then they busied themselves training the team that was to pull the wagon as well as preparing the family's other stock for the long journey ahead. At the same time women took the primary responsibility for items of food, clothing, and medicine which they began to prepare well in advance of the day of departure. Kitturah Belknap left a detailed account of her preparations which consumed all her spare moments during an entire winter.

I have to make a feather tick for my bed . . . the linen is ready to go to work on, and six two bushel bags all ready to sew up ... have cut out two pair of pants for George ... I have worked almost day and night this winter, having the sewing about all done but a coat and vest for George. Will wash and begin to pack and start with some old clothes on and when we can't wear them any longer will leave them on the road. ${ }^{9}$

With the experience of one other migration behind her, Belknap knew what would be needed so despite her exhaustion and ill health she also dipped enough candles to last a year; prepared a complete medicine chest; packed home-sewn sacks with flour, corn meal, dried fruits, and other foodstuffs; assembled dishes and cooking pots; and cooked enough food to last the first week. Her final preparation was to put together a workbasket of sewing so that she wouldn't have to spend any idle moments during the trip. Meanwhile her husband, George, built an ingenious camp table, practiced with the oxen he had selected to draw their wagon, and readied the other stock for travel.

Belknap was delighted with the camp table since it perfectly complemented the ambience she was determined to maintain on the trail. She had already decided to start off with "good 'Ibid. 
earthen dishes" although she was realistic enough to bring tin dishes as a back-up in case the earthen ones were broken. She also had made "four nice little table cloths." With these accoutrements, she declared that she was "going to live just like I was at home." 10

This cooperative venture between men and women in readying themselves, their families, and their goods for the trail resulted in a fully loaded prairie schooner which must have been an impressive sight. It has been estimated that they ranged from 1500 to 2000 pounds, not counting the additional weight of their human passengers. ${ }^{11}$ Many had an assortment of farm animals tied to the back end or dangling in crates tied to the sides.

Moreover, many men and women worked together to incorporate individualized refinements depending on their own needs and inventiveness. The Belknaps prepared a secure spot for Kitturah's rocking chair so that she could ride comfortably while sewing. They also arranged a miniscule play corner for their young son and devised a clever folding bed which would allow them to sleep in the relative comfort of their wagon. The Shuteses arranged their wagon to accommodate Ann Shutes and her infant at night. A common practice, which soon became an accepted part of trail lore, was sewing canvas pouches to the inside of the wagon cover. Catherine Haun found their "pockets" invaluable for small items which needed to be kept in easy reach such as cooking knives, firearms, and toilet articles. ${ }^{12}$

Those people who chose a smaller wagon usually had a shorter distance to cover, but they too were experts at utilizing every possible inch of space. Mary Moore McLaughlin described her family's wagon as "a low, long-coupled, straightbox, two-horse wagon, made roomy and comfortable by an extension of the wagon bed over the wheels." Although it was relatively limited in size, it was crammed with many items, in-

${ }^{10}$ Ibid.

${ }^{11}$ Zenor, "By Covered Wagon," 37.

${ }^{12}$ Belknap, "Reminiscences"; Mary Alice Shutes, Diary, Iowa State Historical Department, Division of Historical Museum and Archives, Des Moines, Iowa; Catherine Margaret Haun, "A Woman's Trip Across the Plains," Huntington Library, San Marino, California. 
cluding some things that were apparently family treasures. McLaughlin especially remembered "mother's little cane seated rocker, our family pictures and books, one bureau, and a jar of honey." Like most other families, the Moores made every effort to create additional space. They hooked a small table upside down on top of the feed box at the back of the wagon to hold "the cooking utensils, the dinner box, the stove rack used for campfire cooking, and two splint-bottom chairs." When it was unhooked it quickly converted into a convenient and comfortable dining area. ${ }^{13}$ These various refinements and additions seem to indicate that some effort was made to provide at least a minimal amount of comfort while on the trail.

Of course, the physical provisions for the journey were only a part of the settlers' total preparations. They also had to begin the process of psychological separation from their families, friends, and neighbors long before they actually began bending the trail grass. The trauma of parting cannot be overemphasized. Unlike modern society where the average person moves many times in his or her life, most nineteenth-century people were accustomed to being part of a region, a town, a neighborhood, and a kinship network. These people shared value systems, social life, customs, and traditions. They shared the joy and the tragedy of births, weddings, and deaths. They called upon each other for help in times of crisis. And they gathered together to pray or to celebrate a holiday.

There is little actual evidence that this emotionally wrenching process was any harder on women than on men. Again, popular myth to the contrary, both men and women seemed to share the pain. Granted, it was more socially acceptable for women to show it than for men; so while Hiram Shutes stole away from his family for a secret farewell with his mother, Kitturah Belknap could openly refuse to attend a last church service because of her emotional state. ${ }^{14}$

A family's decision to leave was not only traumatic for them, but also for those who would be left behind. An announcement of impending departure thus initiated a transition period during

${ }^{13}$ Katharine Horack, "In Quest of a Prairie Home," The Palimpsest 5 (July 1924): 252-253.

${ }^{14}$ Shutes, Diary, and Belknap, "Reminiscences." 
which both the soon-to-be pioneers and those remaining at home attempted to adjust to the idea of separation. The rituals recognizing the coming separation included dinners, dances, family visits, and special church services, all designed to wrap the migrants in a warm cloak of good wishes and friendship of the people they had known for so many years.

Defying their brave attempts to invest the break with a festive air, the morning of the actual departure usually presented a heartrending scene. In the murky early morning light, people gathered around the migrants to help them load their wagon, to serve them breakfast, to grasp their hands one last time, and to wish them luck in the new country. Sleepy-eyed Mary Alice Shutes peered through the dim light of a predawn bonfire to discover that a great number of relatives and friends had come to see her family off and to cook breakfast as a "final display and effort of friendship." She sensed the strain in the air: "The younger kids know something unusual is going on but don't understand it like the older folks do. . . . Some of the older ones seem to welcome the solitude away from the fire ... they have said their goodbyes and are just waiting." Although she sympathized she did not really understand. From her perspective as a thirteen year old, she was thinking more of the excitement of the "good lark ahead of us" than of those to be left behind. ${ }^{15}$

It was a common practice for some friends to ride along with the migrants and their wagons for the first few miles in an extended goodbye ceremony. But as the outskirts were reached, these riders gradually dropped back and returned home, leaving the wayfarers to begin their expedition. As they waved one last farewell to their friends and to the life they had known, the pioneers finally confronted the trail which would transform them into frontierspeople.

$\boldsymbol{S}_{\text {CARY, exciting, intimidating, promising-these and many }}$ other words must have flowed through the travelers' minds as they assessed the scene unfolding before them. Their trepidation may have been allayed somewhat by the fact that they did not

${ }^{15}$ Shutes, Diary. 
lack for company in their trek towards Iowa. One observer went so far as to portray Iowa migration as a mass movement. As early as 1836 he claimed:

The roads were literally lined with the long blue wagons of the emigrants slowly wending their way over the broad prairiesthe cattle and hogs, men and dogs, and frequently women and children, forming the rear of the van-often ten, twenty, and thirty wagons in company. Ask them, when and where you would, their destination was the "Black Hawk Purchase."16

The huge, distended wagons forced their iron-covered wheels into the earthen trail leaving tracks that were reinforced by thousands of wearying footsteps of both people and animals. By the time the migrants converged on Iowa, the marks of their passage were clearly etched on the prairie. Recalling her family's move in the 1860s, McLaughlin later wrote, "I can see now the two tracks of the road, cut deep by the wagon wheels and washed out by the rains." ${ }^{17}$ These tracks became a kind of map for those who followed as well as a testimonial to those who had already completed the demanding journey.

Whenever they had the opportunity, migrants would join with another group to swap information, to exchange bits of trail lore, or to travel together for as long as their routes coincided. McLaughlin remembered that at times they traveled alone, but when possible they joined with other "movers." She remarked that they "were always glad to have company, especially when fording swollen streams, for then we could double up teams and take turns in making the crossing." Her explanation of gregariousness on the trail was perhaps too simplistic. Joining with others, comparing points of origin as well as destinations, and making new friends was at once a tie with a past filled with friends, an attempt to maintain identity in a world which reduced everyone to a common denominator, and practice for a future which would demand the establishment of many new contacts. Hiram Shutes, as a case in point, was

\footnotetext{
${ }^{16}$ Quoted in Bruce E. Mahan, "The Iowa Pioneers," The Palimpsest 49 (July 1968): 247.

${ }^{17}$ Horack, "In Quest of a Prairie Home," 254.
} 
enthusiastic as well as touched when he met someone from his home region or someone who planned to settle in the same area of Iowa as his family. ${ }^{18}$

Some migrants, perhaps anticipating the anonymity and anomy of the trail, traveled in groups. When the Willises announced their intention to relocate in Iowa they were surprised and pleased to learn that "most of the immediate relatives soon sold their homes, loaded their goods into wagons, and started for Iowa" with them. They traveled as a group helping each other whenever they could by "fording streams, wading through mud, and enduring untold hardships" together. The Harris family put together a very similar kind of caravan. Numbering ten people, they moved along in two huge covered wagons pulled by yokes of oxen as well as in a two-seated buggy pulled by a team of horses. ${ }^{19}$

What neither of these chroniclers articulated was the hedge the family caravan formed against the onset of loneliness, the disintegration of family unity, and the often stark aspects of the moving frontier. Furthermore, neither they nor many other Iowa women writers specifically discussed why they had placed themselves in such a threatening, albeit potentially fulfilling, situation. Of the few that even mentioned motivation, Mary Ann Ferrin stated that she "was fond of adventure and preferred to go with my husband." Similarly, McLaughlin said that her mother liked to move: "father always said that whenever he wanted to move he had only to tell mother of his plans and she was ready and willing to go." 20

According to the traditional image, however, a woman was simply an appendage to the males of the family; her husband, father, or brother made the decision for her and in the proper manner of a "True Woman" of the nineteenth century she accepted that decision. This stereotype of the female migrant as an appendage of the male migrant even clouds attempts to

${ }^{18}$ Ibid; Shutes, Diary.

${ }^{19}$ Bessie L. Lyon, "Grandmother's Story," The Palimpsest 5 (January 1924): 4; Haines, "Seventy Years in Iowa," 103-104.

${ }^{20}$ Mary Ann Ferrin Davidson, "An Autobiography and a Reminiscence," Annals of lowa 37 (Spring 1964): 245; Horack, "In Quest of a Prairie Home," 250 . 
understand the motivation of the unmarried woman, that is, the female migrant who made the decision to move on her own rather than in conjunction with other family members, especially male family members. It has generally been assumed that the unmarried female relocated only to become an appendage; in other words, she moved west to marry one of the surplus male settlers already in Iowa.

Such thinking obviously reflected a society in which all women were expected to marry and in which the preponderance of women actually did marry. Despite the emergent feminist movement of the 1840 s, marriage was still seen by most Americans as the only appropriate be-all and end-all of a young woman's life. It is not surprising then, that many young women capitalized on the population imbalances in Iowa to further their own marital careers.

Regardless of the stereotyped thinking of the era about women, many ambitious single women did head for the Iowa frontier as laborers, missionaries, and teachers. Catharine Beecher in particular encouraged groups of women teachers to choose western careers, because she saw employment opportunities for them and because she regarded women as civilizing influences necessary to a new society. In addition, some unmarried women moved, as did men, to take up land although the data on them are incomplete at best and impressionistic at worst. Unfortunately, curiosity butts it head against Newhall's 1846 guide to Iowa which listed only the occupation of dairy maid as a possible job for a woman, against gazetteers and almanacs that reflect women primarily as seamstresses and dressmakers, or worse yet, against Iowa census reports that sometimes categorized women as "not gainfully employed." 21

If assessing the motives of the single woman is difficult, the task of unearthing the motives of married women (or women otherwise part of a family unit) is nearly impossible. Because they were dependent members of these family units, their part in the decision-making process was usually obscured by the

${ }^{21}$ Kathryn Kish Sklar, Catharine Beecher: A Study in American Domesticity (New York: W. W. Norton \& Company, Inc., 1976), 97-98, 102; John B. Newhall, A Glimpse of Iowa in 1846; or, the Emigrant's Guide (Iowa City: State Historical Society, 1957), 61. 
aggregate family decision. As a result, some rather tenuous suppositions have been formulated. One of these argues that many women had no motivation beyond obeying or pleasing their husbands. Another holds that since income production was the husband/father's ascribed duty in nineteenth-century society, he made the decision as to how and where that income would be produced and the rest of the family had to acquiesce. ${ }^{22}$

Certainly, nineteenth-century society cast men in the role of bread-winners, initiators, and decision-makers, but Iowa women's maruuscript sources do not uphold a theory of repression towards them. Rather, women in family units ran the gamut from acceptance of, identification with, or support of, to initiation of the idea of settling on the Iowa frontier. As these women touched upon their feelings about migrating to Iowa the emotion which most often surfaced was one of optimism rather than bitterness. And like men, they too were sensitive to the pushes and pulls which caused their friends, neighbors, relatives, and ultimately themselves to decide to uproot their ties, their lives, and their families. These pushes and pulls, after all, tended to be oblivious of gender. Women were not dumb and blind; they could see worn out lands, the poor health of a family member, or the richness of the West as well as men could.

\section{W}

HATEVER THEIR INITIAL MOTIVATIONS, Iowa women tended to respond to the demands of the trail with hard work, generally buoyant spirits, and relatively few complaints. In the four basic areas of enterprise necessitated by the moving frontier they usually made sincere, and often highly successful, attempts to achieve and even excel.

The first area, the performance of all the regular chores connected with daily living, was not only time-consuming for women (whether at home or on the trail), but it was made even more troublesome by the primitive conditions of the trail. To

${ }^{22}$ See for example Faragher and Stansell, "Women and Their Families on the Overland Trail," 153 and Stansell, "Women on the Great Plains," 90. For a different view, see Julie Roy Jeffrey, Frontier Women: The Trans-Mississippi West, 1840-1880 (New York: Hill and Wang, 1979), 32-34. 
the credit of most trail women, they cared for the needs of their families in as homelike an aura as they could create during the time the wagon was their only home and the trail their only backyard.

One of the easier problems for them to resolve was their families' sleeping arrangements. The wagon presented itself as an obvious "bedroom" and many of the wayfarers took advantage of its minimal protection. The Titus party was delighted to find that its two wagons "were roomy enough for all," but they did not remark on the comfort or the space provided by their accommodations. Most groups found that all members would not fit into the wagons so they turned them over to the most needy members: the aged, the ill, the small children, or the women with infants. The Harrises developed another alternative; whenever they could locate a tavern they boarded the women of the party there while the men slept nearby in the wagons. ${ }^{23}$ Others utilized tents, deserted houses, or simply slept outside, using a variety of quilts, feather ticks, or corn husk mattresses to shield them from the chill air and the unrelentingly hard ground.

Most campers combined a night watch with an all-night fire to protect their camp. Shutes mentioned that "the men folks arranged about turns for night watch to watch the stock and keep the fire going as a warning for intruders to keep away." Later in her diary she reported that they had a "nice campfire going to keep wild animals away-mostly the small kind." The eerie shadows created by the flickering fire combined with the noises of a wilderness night must have provided a strange and frightening backdrop for the travelers. Recalling the night she spent in the wagon as a small child, McLaughlin vividly remembered that, "as the twilight settled into darkness, the wolves came slinking around the camp; and while they howled we children snuggled closer together in our beds in the wagon box, begging father to build the fire higher." 24

Occasionally, some travelers were fortunate enough to be afforded shelter for a night by a friendly family who still re-

${ }^{23}$ Lydia Arnold Titus, "From New York to Iowa," ed. Bruce E. Mahan, The Palimpsest 2 (October 1921): 319; Haines, "Seventy Years in Iowa," 104.

${ }^{24}$ Shutes, Diary; Horack, "In Quest of a Prairie Home," 254. 
membered its own trek west. For Kitturah Belknap one instance of such hospitality was particularly welcome. The Belknap party crossed an eighteen-mile stretch of prairie in the freezing snow during which Kitturah drove the team so her husband could herd the stock. "I thought my hands and nose would freeze," she related. "When I got to the fire it made me so sick I almost fainted." Luckily, they were taken in by a family of eight people living in a tiny, isolated cabin. Belknap thawed out her frozen provisions for dinner and then, sick with a toothache, she bedded down on the floor with the other five members of her party. They arose at four a.m. in order to eat breakfast without disrupting their hosts and set off for more miles of snow-covered prairie somewhat refreshed by the brief interval spent indoors. ${ }^{25}$

The Shuteses' situation was not nearly so desperate when they met with a hospitable family who had come to Iowa in the 1840 s and had been helping migrants ever since. The Shuteses had just been chased out of a deserted log cabin by what the children called "striped kitties," but which were more correctly identified by their father as skunks. After their close escape, they were happy to spend a night in the host family's barn and to be treated to a breakfast of buckwheat cakes, fresh side pork, and coffee. Mary Alice was especially pleased with the meal because "you could eat your fill with no smokey taste." 26

Mary Alice's observation regarding the breakfast highlights the fact that women had a much harder time feeding their families than they did figuring out where they would sleep. Women tackled the arduous job of meal preparation by developing a trail-craft, the ingenuity of which rivaled the woods-craft or plains-craft of their male counterparts. Using reflector ovens, prairie stoves, or just campfires, they concocted meals which ranged from adequate to wonderfully unforgettable.

Lydia Titus was particularly adept at campfire cooking. She "fried home-cured ham or bacon with eggs" while she "boiled potatoes or roasted them in the hot ashes." The Lacey family settled for a cold lunch from a big barrel that Sarah had packed with suitable provisions, but at night she insisted upon cooking

${ }^{25}$ Belknap, "Reminiscences."

${ }^{26}$ Shutes, Diary. 
them all a hot meal over a campfire. She prided herself on always offering them "meat or eggs and a warm vegetable for all, as well as pie or cake." McLaughlin recalled a homey scene focusing on prairie chicken:

... father would bring water, build a fire and take down the little green table and splint-bottom chairs from the back of the wagon, while mother prepared the meal. We were at home on the prairie with prairie chicken for supper ${ }^{27}$

Another woman's diary referred to cooking over an open fire, cooking in the rain, and cooking food on Sunday to be eaten during the first part of the following week. One Sunday her project of fixing beans was interrupted by a sudden rain shower. "Wasn't it a shame!" she lamented. "Mine were almost done when a shower came up and drove me into the wagon. The beans taking advantage of my absence burned up. Nothing was left for me but to cook more." Like many trail women, she augmented her cooking facilities with whatever resources came to hand. At one camp spot she made biscuits after obtaining permission to bake them in a nearby house and at another she prepared eggs on a borrowed campstove. ${ }^{28}$

As the migrants neared lowa, the task of food preparation became more difficult due to decreasing fuel supplies. The prairies did not readily yield wood for their fires so the pioneers often had to purchase wood just as they did food. When wood was totally unavailable, they twisted hay, prairie grass, or slough grass into "cats." This created an extra job for the women and children who had to spend hours in producing fuel by collecting and twisting the hay or grass, but it was perhaps more agreeable than the other widely employed option of collecting dried animal excrement, euphemistically called cowchips or buffalo-chips, for use as fuel. ${ }^{29}$

${ }^{27}$ Titus, "From New York to Iowa," 319; E. May Lacey Crowder, "Pioneer Life in Palo Alto County," Iowa Journal of History and Politics 46 (April 1948): 162; Horack, "In Quest of a Prairie Home," 254.

${ }^{28}$ Jane Augusta Gould, Diary, Iowa State Historical Department, Division of the State Historical Society, Iowa City, Iowa.

${ }^{29}$ Robert L. Munkres, "Wives, Mothers, Daughters: Women's Life on the Road West," Annals of Wyoming 42 (October 1970): 198. 
Another problem of the prairie region, limited water supplies, made it increasingly difficult for the women to effectively wash the clothing and bedding of the party. When the rain barrels were full, when a farmhouse with a well was located, or when a stream was reached, the women and girls seized the opportunity to refresh garments dirtied and worn by traveling in heat and dust. Gould's note regarding clothes washing was typical. "At four p.m. I commenced and did a real large washing - spreading the clothes on the grass at sunset." At a later point in her diary she expressed shock because, while they were "laying over because it was the Sabbath," she discovered that "the women were doing up their week's washing!"30

Gould's observation offers a critical insight into women's work on the trail: their tasks were often out of pace with the rhythm of other trail work. Rest periods for the men and younger children, such as meal stops or evenings, were the very times women began their chores. Then, of course, to complicate matters even more there was the ever-present task of childcare. Any attempt to determine the proportion of children on the trail is thwarted once again by the lack of census data regarding the trail experience. Although their actual numbers remain a matter of conjecture, mention of their existence is liberally scattered throughout women's sources. ${ }^{31}$ Moreover, there is little indication that anyone thought it unusual for children to make the demanding trip, even at very tender ages.

The story of Lydia Titus is fairly representative. In 1869, when she and her husband resolved to make Iowa their new home, her young sister and her husband announced that they were going along. Both couples sold their farms and stock, "keeping only a wagon apiece and four horses," to transport themselves and their four children. Lydia had an eight-year-old daughter, a three-year-old son, and a ten-month-old girl while her sister had a six-week-old baby girl, yet neither woman visualized moving such young children as an extraordinary undertaking. They soon learned that they were not alone in

${ }^{30}$ Gould, Diary.

${ }^{31}$ Faragher and Stansell, "Women and Their Families on the Overland Trail," 156; see Read, "Women and Children on the Oregon-California Trail," for a discussion of the number of women and children on the Overland Trail. 


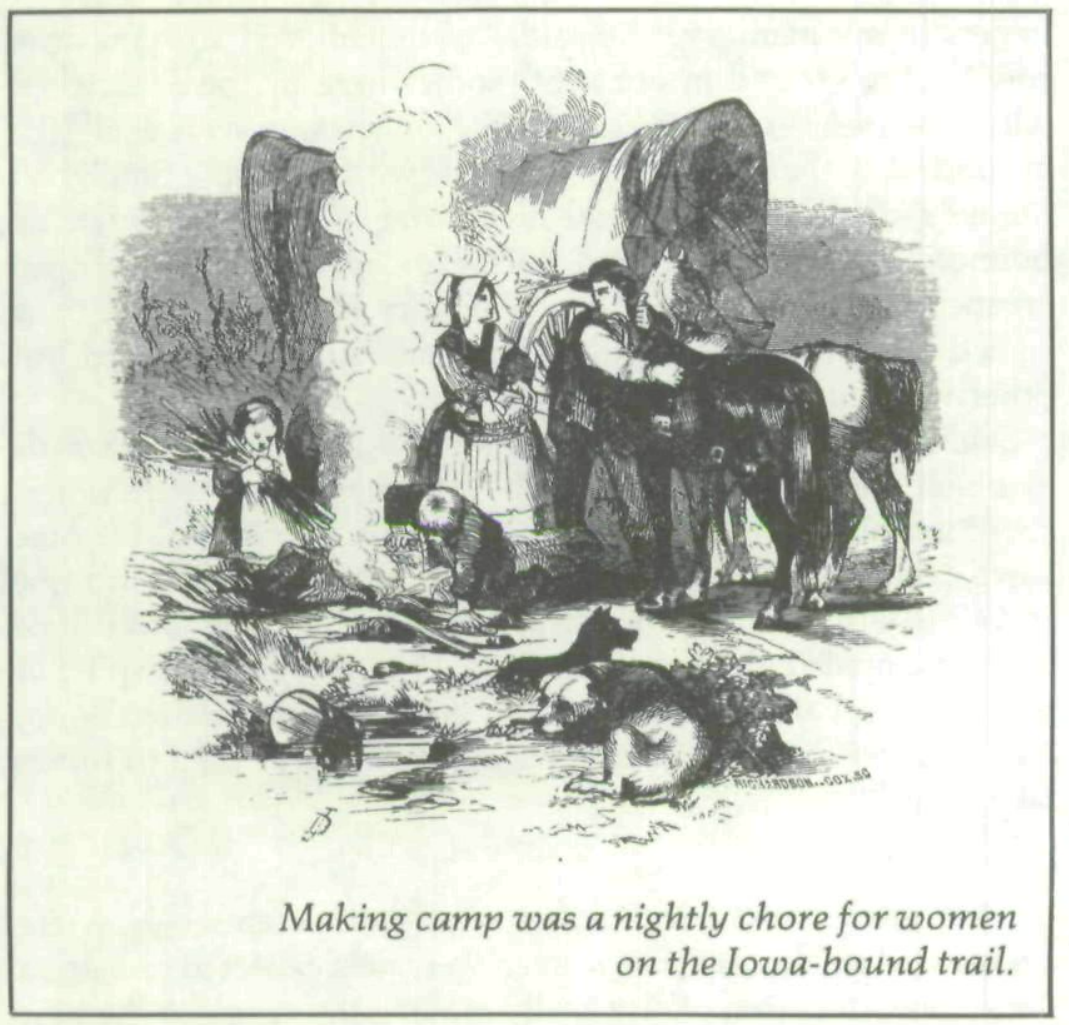

their decision. There were many others, such as the Archers, who with four wagons were moving nineteen people; thirteen were children between the ages of two and the early twenties. ${ }^{32}$

For trail women, the problem of physically protecting the children was in all probability the most distressing aspect of childcare on the trail. Despite their constant vigilance, children often got too far off to the side of the road or lagged too far behind the train, causing their parents more than a few anxious moments. Furthermore, the possibility of accident, illness, and disease constantly hovered over them. Although they carried some medicines, they knew that the services of a doctor would be virtually unobtainable in case of serious trouble. Elisha Brooks always remembered the starkness of the situation when illness hit him and the other children of his party. "A picture

${ }^{32}$ Titus, "From New York to Iowa," 318-319; Margaret E. Archer Murray, "Memoir of the William Archer Family," Annals of lowa 39 (Fall 1968): 369. 
lingers in my memory," he said, "of us children all lying in a row on the ground in our tent, somewhere in Iowa, stricken with the measles, while six inches of snow covered all the ground and the trees were brilliant with icicles." Similarly, Shutes recorded the terror she faced when sleepy young Archie bounced off the wagon and barely escaped having his head crushed by the wagon wheel. "Am sure luck is with us," she sighed with relief upon finding out that Archie was dazed but otherwise uninjured. ${ }^{33}$

Evidently, the migrants themselves did not see these hazards as much greater than those of their former lives for they persisted in undertaking the trip with babies and children. In some cases, optimism offset the threat of adversity. One couple traveling with two infants was described as "young and full of hope and made light of the hardship." In other cases, a spirit of necessity prevailed. As "Grandmother" Brown summed it up, "then I never thought about its being hard. I was used to things being hard." 34

T

HESE MANY TASKs, demanding enough in themselves, were aggravated by the fact that women were also expected to help in the second area, that of physically moving the group to the new land area. When the caravan was on the move women were not relieved of duties. Childcare naturally continued, but women also contributed to what were generally male tasks such as driving the team and herding the stock. Haun called it lending "a helping hand." She explained that, "the latter service was expected of us all-men and women alike." Belknap, for instance, frequently took over the lines and drove the team to free her husband to tend the unruly stock. And Lyon's mother routinely drove the wagon part of each day so that her husband could stretch his legs by walking behind it. When their wagon

${ }^{33}$ Quoted in Ruth Barnes Moynihan, "Children and Young People on the Overland Trail," The Western Historical Quarterly 6 (July 1975): 292; Shutes, Diary.

${ }^{34}$ Crowder, "Pioneer Life in Palo Alto County," 156; Harriet Connor Brown, Grandmother Brown's Hundred Years, 1827-1927 (Boston: Little, Brown and Company, 1929), 103. 
became mired in mud, she even mounted their horse and, with "the baby in her arms" and her small son astride behind her, guided the horse in rescuing the wagon. ${ }^{35}$

Women also engaged in the battle against sun scorched prairies, biting snow storms, mud sloughs, and wide streams and rivers. The latter could often be forded or ferried across with comparative ease, but in some cases their depth or flooded condition due to a recent storm presented a great barrier to settlers, their wagons, and their animals. This resulted in some classic tales of groups pushing ahead with the help of their women. In 1832, for example, Caroline Phelps and her husband were stymied by flooded Sugar Creek which they finally crossed by swimming on horseback and floating on driftwood. In the process, Phelps, who already suffered an eye swollen shut by an infection, was knocked down and kicked in the forehead by a frightened horse. She roused herself sufficiently to pick up her baby and get them both across the creek, after which the men of the party brought their wagon across in pieces. Her comment on the affair demonstrated her vigor: "we had a good supper and a good bed . . . the next morning I was quite refreshed." 36

Even if they escaped these kinds of perils, all of the Iowabound migrants had to confront the Mississippi River. Throughout most of the pioneer period, railroads and highways alike ended abruptly on the east bank leaving the settlers to traverse the river by boat or ferry. Bridges across the Mississippi were not constructed until the late 1860 s due to the bitter opposition of steamboat companies and ferry operators so, in spite of steadily improving technology, settlers had to deal with this impediment to their progress.

For most people, crossing was a time-consuming but interesting event. When the Shuteses reached the Mississippi, they learned they had just missed a bad flood which had prevented crossings of any kind for several weeks. "Not just too much water," they were informed, "but too much trash and big trees

${ }^{35}$ Haun, "A Woman's Trip Across the Plains"; Belknap, "Reminiscences"; Lyon, "Grandmother's Story," 4-5.

${ }^{36}$ Caroline Phelps, Diary, Iowa State Historical Department, Division of the State Historical Society, Iowa City, Iowa. 
that would smash anything in their way." Fortuitously, Hiram had been advised to arrive ahead of his party and get their name "in the pot" for a place on the ferry so they had to wait less than a day. When they left their camp spot and approached the ferry, they were quickly caught up in the excitement of throngs of people, escalating noise levels, animated talk of high water, and piercing blasts from the whistle of the steam-powered ferry. As they gradually edged up the loading plank, the men took responsibility for the wagons, the children led the blindfolded horses, and the mother shepherded the small children. Once out upon the swirling waters, Shutes felt that her mother had "the real job sitting on a chair holding the baby and Howard." 37

For some women, the crossing was not this easy. In the mid1860 s a lone woman who had already managed moving herself and four children under age eleven to join her husband in Iowa, was appalled to learn that cracking ice on the Mississippi River prevented teams from transporting any more settlers over it that winter. She was told that she would have to wait until the ice cleared and the ferries began to run again. Faced with four exhausted children and a diminished cash reserve, she decided to join a few others who were walking to Iowa over the groaning ice floes. She picked up the baby, distributed the luggage among the older children, and set out. Her daughter later recounted their perilous crossing:

I can see yet, as in a dream, that great expanse of gray ice. Even then it was cracking, and as we went on there was a low grinding sound .... we were constantly warned not to crowd together or we would break through. Mother who, with all her burdens, was clipping along with the rest would call out cheering and encouraging me to come along. I don't think she had realized how wide the river was, how far the distant shore.

When asked what had given her the courage to keep going across the splitting ice, she replied, "I was thinking of your father and all he had been writing about you children growing up in Iowa." 38

${ }^{37}$ Shutes, Diary.

${ }^{38}$ Francis E. Whitely, "Across the Mississippi," The Palimpsest 15 (January 1934): 13-15. 
Obviously, time on the trail was far from dull for most women; neither was it uninstructive. As they carried out their chores and helped with the other trail work they were concomitantly developing themselves in the third area-the sharpening of the skills that would serve them so well both on the moving frontier and in their new homes. Since they were predominantly farm women in origin they were not naive about what would be required of them; food processing, cooking, spinning, weaving, and a myriad of other skills were already in most of their repertoires. Yet, on the trail, they demonstrated creativity, and at times pure genius, in the way they adapted them to the conditions at hand.

Kitturah Belknap was a perfect illustration. Using a Dutch oven, a skillet, a teakettle, and a coffeepot, she devised meals which were just like "at home." These regularly featured her salt-rising bread which she worked at in between her other chores.

When we camped I made rising and set it on the warm ground and it would be up about midnight. I'd get up and put it to sponge and in the morning the first thing I did was to mix the dough and put it in the oven and by the time we had breakfast it would be ready to bake. Then we had nice coals and by the time I got things washed up and packed up and the horses were ready the bread would be done and we would go on our way rejoicing.

Butter for the bread was not a problem for Belknap either. When the cows were milked at night, she strained the milk into little buckets which were covered and set on the ground under the wagon. In the morning she skimmed off the cream, put it in the churn in the wagon, and after riding all day she had "a nice role of butter." Kitturah further supplemented their meals with foodstuffs bought along the way. She would keep her eye out for a farmhouse where she might purchase a head of cabbage, potatoes, eggs, or other fresh foods. She soon became trailwise: "where there were farms old enough to raise anything to spare, they were glad to exchange their produce for a few dimes." ${ }^{39}$

${ }^{39}$ Belknap, "Reminiscences." 
Despite the prevalence of this kind of grit, there were some women who never did make it in the last area-changing their mind-set from eastern in orientation to western. Some of these, regretting their decision or finding themselves unable to cope with the demands of migration, voluntarily turned back. Like every society, the trail had a certain number of misfits, but these were not only women for some men also decided to terminate the venture. As one woman pointed out, "some liked the new country, but others . . . returned to their native States." 40

Some scholars have argued that the work which women performed and the mental anguish they endured on the trail was not repaid by a bond of inclusion in what was essentially a maledirected undertaking. They have claimed that in consequence women soon became alienated and disheartened by the migration experience. ${ }^{41}$ If Iowa women experienced these feelings, they generally avoided recording them. Perhaps they realized that any domestic routines they could recreate, any assistance they could offer, and any supportive feelings they could extend were all necessary to the preservation of their families and themselves under the duress of migration. Most seemed to understand that their tasks, whether in material or psychological realms, were absolutely essential in subduing the trail and getting their families to the promised land.

For the most part, they seemed at least to keep open minds toward both the frontier in transit and the frontier in Iowa. More often than complaint, Iowa trail women expressed a sense of equanimity. This was apparent in Gould's remark that it was "decidedly cool camping out and cooking by a campfire, but we must do as we can." It was also reflected in Shutes's statement that "we have a lot of weary miles behind us. Glad to have done it but would not care to do it over again, or very soon anyway." Furthermore, the harshness of the trail environment was often leavened by a spirit of fun. Singing, dancing, and good-natured courting were frequently part of the scene as the settlers moved closer to their new homes. The following diary notation was

${ }^{40}$ Titus, "From New York to Iowa," 315.

${ }^{41}$ Faragher and Stansell, "Women and Their Families on the Overland Trail," 160; Stansell, "Women on the Great Plains," 87-90. 
not uncommon: "I hear the merry notes of a violin. A general cheerfulness prevails." 42

Had these women been totally hardened and bitter, they could not have been as awed and as pleased as they were by the prairie country which gradually enveloped them. One exulted that "the prairies were just one great flower garden." Another remembered how her family learned to love the open prairie as they traveled across its broad expanse. Another emphasized that she could not adequately describe "the magnificence of the wild flowers that made the prairies for miles in all directions one gorgeous mass of variant beauty." And yet another called it "a perfect garden of Eden." 43

It appears then, that in challenging the trail, many Iowabound women also challenged the nineteenth-century stereotype that women were weak, emotionally insecure, and capable of existing only within the confines of a home tucked away from the realities of a harsh world. Although the westward journey broke and embittered some women, so many emerged from it intact or even strengthened that it is unconscionable to generalize any longer. Many trail women were strong because, in reality, life for most nineteenth-century American women was difficult in spite of their location. As one woman put it, her parents survived the crude conditions of the road because "their early lives had been spent amid such surroundings." 44 That their lives were not easy, or even satisfactory at home, was the very reason that most people were on the trail. It was tough, but at least it offered the hope of increased rewards for their deprivation and toil.

$\mathrm{M}_{\text {ANY of these trail women not only survived the trail, but }}$ they went on to settle the Iowa frontier, to live to tell about it, and often to recount many happy times as well. And a great number became trail women again in their life, this time tack-

${ }^{42}$ Gould, Diary; Shutes, Diary; Gould, Diary.

${ }^{43}$ Cowles, Early Algona, 123; Horack, "In Quest of a Prairie Home," 253; Haines, "Seventy Years in Iowa," 104; Mrs. E. A. Hadley, Journal, Iowa State Historical Department, Division of the State Historical Society, Iowa City, Iowa.

${ }^{44}$ Crowder, "Pioneer Life in Palo Alto County," 156. 
ling the overland route to the Far West. Kitturah Belknap, Lucy Cooke, E. Allene Dunham, Eliza Ann Egbert, Catherine Haun, and Virginia Ivins were only a few of the Iowa women who eventually went on to cross the Plains in order to pioneer the Far West just as they had pioneered Iowa. And on the overland route, as on the trail to Iowa, they recorded positive impressions of their trek.

As one might expect from previous descriptions of Kitturah Belknap, her mettle and spunk survived the long route to Oregon in 1848. She prided herself on having the only dinner table in the train with a cloth on it, she industriously sewed and mended in her spare moments, and she became an adept trader with farmers, emigrants, and Indians in order to supplement their food supply. Although she noted the fear aroused by the presence of Indians and Mormons, a quarrel in the next wagon caused by a husband's refusal to give in to his wife's demands to turn around, and her son's serious illness, her own spirits remained high. Thus, her description of the journey was sprinkled with comments such as: "the road is good and I am standing the riding fine," "it is a fine spring morning," "have had fine weather, good roads and all have been well," and "I have washed and ironed and cooked up a lot; find our appetites improve the longer we are out." 45

A similar mood emanates from the trail letters of Lucy Cooke, a young mother with a year-old baby who emigrated to California with her husband and his parents in 1852 . Her mother-inlaw's lamentations about the trip, frequent outbreaks of cholera, and the rigorous mountain crossings failed to intimidate her. She too was able to find "luxuries" along the trail: candy and preserves from Ft. Laramie, a fine dinner in a boarding-house in Salt Lake City, and an impressive collection of furs garnered from trading some of her goods with Native Americans. At Salt Lake she wrote her sister back in Iowa that, "so far as we have come, there's nothing to fear on the road. Two-thirds of the distance has been good as a turnpike road. . . . I wish I were seated in your snug parlor, telling the wonders of travel." 46

${ }^{45}$ Belknap, "Reminiscences."

${ }^{46}$ Lucy Rutledge Cooke, Covered Wagon Days: Crossing the Plains in 1852 (Modesto, California: Privately published, 1923), 7-37, 41-44. 
Actually, it was her husband William who was depressed by the trip, rather than Lucy. She told her sister that,

William often wishes we were back, and says so soon as he gets any more than he started with he'll be with you. If I were very anxious I think William would send me back to you in the spring, and he go on alone to California; but it looks best we journey together.

During their next lap, four months to California, she wrote, "so far enjoy ourselves. . . . We live first rate." And when they finally sighted Lake Tahoe, she rejoiced that "our trials would soon be of the past, whilst the future, oh, where was the limit?"47

Because E. Allene Dunham crossed the trail to California as a young girl with her family in 1846 her remembrances are of a slightly different nature. She did, however, mention amenities such as camping at a farm, her mother and the baby staying in a hotel, staying in an emigrant campground, and buying milk from farms along the way. She remembered a few unfriendly Native Americans, but said that the majority acted pleasantly, begged for food, and invited the emigrants to visit their camps. Dunham's other recollections centered around gathering wild flowers, playing on rocks, hiding in the sagebrush, and the highlight of the trip, being taken to mountain peaks by some young women of the train who "took their revolvers and we had a fine time." Her conclusion: "We children knew nothing only to enjoy ourselves, and we surely did." 48

Like Dunham, Eliza Ann Egbert crossed the Plains in 1852 as a girl. Although she noted accidents, deaths, "impudent" Indians, and loss of stock, she did not dwell upon them. Instead, she noted her appreciation of "a beautiful camp ground near a little stream on the prairie," "fair weather today and good road," "delicious water," and "good grass." Her son was later to say of her,

No doubt the young emigrants endured many hardships, but if so, they are not stressed in the diary, nor do I remember

${ }^{47}$ Ibid., 49, 60-70.

${ }^{48}$ E. Allene Taylor Dunham, Across the Plains in a Covered Wagon (n.p., n.d.), 1-20. 


\section{The Annals of Iowa}

that they were ever mentioned by my mother in the many times I have heard her speak of the trip. To them it was the big adventure and the hardships were accepted as part of that adventure. ${ }^{49}$

Catherine Margaret Haun, on the other hand, made the trip as a young bride in 1849 due to family financial trouble and her own poor health. She maintained that the hazards of the trail did not frighten her. "Indeed," she wrote, "as we had been married but a few months, it appealed to us as a romantic wedding tour." Overall, the trail proved therapeutic for her: "In my case, as in that of many others, my health was restored long before the end of the journey." The first few days of the trip, however, she found to be extremely tiresome and she described herself "dazed with dread." She avoided confiding her fears to her husband because she didn't want to add to his burdens for she believed that "he would certainly have turned back for he, as well as the other men of the party, was disheartened and was struggling not to betray it." 50

From that point on her frame of mind improved and she even surprised herself by offering, despite her lack of experience, to do all the cooking for her party when the hired cook quit. She found her companions to be "a wonderful collection of people," the youngest of whom was a six-week-old baby. Like the other women of the train, she helped drive the wagon, cared for the children, and caught up with her washing and mending on Sundays. Although they were passed by many discouraged emigrants returning east along the trail, she urged her husband onward. She was more than pleased that they were among the dozen or so people out of the original 120 in the train that reached Sacramento as scheduled. ${ }^{51}$

The last tale of the overland trek was written by Virginia Ivins, a Keokuk woman who left for California in 1853 with her husband, one-year-old son, aunt and uncle, five drovers, and a German cook named Carl. Around the time they neared Ft. Laramie she noted that, "On the whole we were having a rather

${ }^{49}$ Eliza Ann Egbert, Travel Diary, California Historical Society, San Francisco, California.

${ }^{50}$ Haun, "A Woman's Trip Across the Plains."

${ }^{51}$ Ibid. 
good time; were all well, were becoming inured to privations, and things were moving along quite satisfactorily." She was aware that frequently there were Indians around but said they never bothered the camp. Although only twenty years old, she often cheerfully helped with the heavy cooking chores. And near the end of the journey, when she felt seriously ill, she stated that she "simply endured without complaint" but "made the best of the somewhat difficult situation and was quite cheerful when my husband was with me." When foul weather and broken-down wagons beset them she went to the aid of her husband because he was "altogether discouraged, hardly knowing what to do and seemed to depend on me for advice." 52

When, near California, he was offered several lucrative jobs they decided to continue on their way since, according to Ivins, "ease had no charms for us then." She basked in the limelight created for her by the scarcity of women, remarked often on the lovely weather, and congratulated herself for having remained "perfectly cool in every danger we had encountered." When the end was finally sighted she found herself "almost jubilant" to have survived a "most trying and tedious journey" successfully. ${ }^{53}$

Here, then, are the stories of six representative women who crossed the most feared trail of all-the route across the Plains to the Far West. Yet the conditions they recounted and the emotions they expressed were very similar to those of many women on the Iowa trail. There was a hardiness, a creativity, a buoyancy of spirit on the part of all these women that makes one wonder if the frontier in transit was as detrimental to women as myth would have us believe. The similarities were more than coincidental; the goods purchased along the way, the enjoyment of scenery and climate, the lack of serious problems with Native Americans, the shoring up of tired and discouraged men, the determination to reach the intended destination were all recurrent themes which cannot be ignored. The replacement of the image of trail women with a more balanced picture is clearly long overdue.

${ }^{52}$ Virginia Wilcox Ivins, Pen Pictures of Early Western Days (Keokuk, Iowa: n.p., c. 1905), 52-69, 96, 101, 111, 114.

${ }^{53}$ Ibid., 116-120. 
Copyright of Annals of Iowa is the property of State of Iowa, by \& through the State Historical Society of Iowa and its content may not be copied or emailed to multiple sites or posted to a listserv without the copyright holder's express written permission. However, users may print, download, or email articles for individual use. 